\title{
Doping in sport: what is the right thing to do? \\ Ibrayeva B. ${ }^{1}$, Kalizhanova A. ${ }^{2}$ (Republic of Kazakhstan) Допинг в спорте: быть или не быть? Ибраева Б. М. ${ }^{1}$, Калижанова А. Н. (Республика Казахстан)
}

\author{
${ }^{1}$ Ибраева Баян Мукушевна / Ibrayeva Bayan - кандидат филологических наук, профессор \\ ${ }^{2}$ Калижанова Анна Николаевна / Kalizhanova Anna - преподаватель английского языка, \\ кафедра иностранных языков и межкультурной коммуникации, педагогический факультет, \\ Академия «Болашак», г. Караганда, Республика Казахстан
}

\begin{abstract}
: only the laziest person did not take part in recent discussion on the matter of doping in sport that made sense of chaos in global sports communities as well as world political arena. As a result, the number of people who believed in fair and square attitude to athletes despite their national flag and anthem reduced significantly. The dilemma regarding the presence or absence of medical aid in professional games went beyond another choice 'to be or not to be.' This article aims to answer if it is possible to get rid of doping at all and how to clear thousands of professionals from being suspected of using doping to win at all costs.

Аннотация: даже ленивый принял участие в недавней дискуссии на предмет допинга в спорте, который спровочировал хаос в мировых спортивных и политических кругах. В результате, людей, которые верят в справедливое отношение к спортсменам, несмотря на национальный флаг и гимн, становится все меньше и меньше. Дилемма относительно употребления допинга вышла за рамки внутренней. Цель статьи - попытаться определить вероятность полного избавления от допинга 8 спорте и восстановления репутации тысяч спортсменов со всех уголков земного шара.
\end{abstract}

Keywords: doping, athlete, sports community, public opinion, get rid of doping, professional games, injuries. Ключевые слова: допинг, атлет, спортивный комитет, общественное мнение, избавиться от допинга, профессиональный спорт, травмы.

For the last decade, numerous scandals connected with doping consumption shook the world. Public opinion strongly condemned those who used doping for various reasons. The recent scandal with Russian athletes cast a shadow of mistrust over the whole country and national sports federations. As a result, only 270 athletes out of 400 declared participants were allowed to take part in Rio Olympic Games 2016. The fight against drug cheats has reached its culmination, and, at the same time, has hit a dead end. The paradoxical situation has arisen in the professional sport. On the one hand, the big game demands results, which are not in the realm of possibilities. One the other hand, there is a prohibition of drugs used to maintain the athletes' health and deal with any grueling physical exertion.

The occasion with Russian athletes is not the only one in the global sports community. History knows a majority of cases when champions from various countries immediately became outcasts after a proven fact of doping consumption. Lance Armstrong, an American cyclist, was recognized as a national hero for a long time. He managed to recover from the cancerous disease, made a glorious comeback to the professional sport and succeeded in seven Tour de France bicycle races during 1999-05. After being accused of the doping usage by his teammate [5], Lance admitted his fault regarding drug cheat during the TV show in January 2013. His confession of guilt caused a massive scandal. This superhero served as an example of a strong will to victory worth to be copied by any other athletes, but, as a consequence, gave all his medals, prizes and financial bonuses earned from 1998, back. For last, Armstrong claimed that nobody could have won such an exhausting tournament without any steroids due to extensive physical activities [3].

So, the dilemma, if the sportsmen should use performance enhancing drugs or not, is vital and up-to-date. However, it is tricky to give a clear-cut answer. Of course, from the perspective of the majority the usage of doping is beyond all ethical and moral norms established in our society [2]. But who, when, and why decided that such medicine is evil. From ancient times philosophers did not succeed in identifying what 'good' or 'bad' meant because of the matter of 'good' or 'bad' as a question of humanity's agreement in Human World. Thus, such agreement does not mean an absolute truth. History knows many examples when changes of power caused changes of reality. Moreover, for the same actions in the same country people can be appraised, punished or sentenced to death. In Holland, for instance, gay marriages are legal, whereas in some Muslim countries, forbidden due to the local legislation.

Doping has not become an exception regarding the choice whether to use or not. If WADA, a group of individuals organized to handle all doping issues, decided against some enhancing drugs it does not make it right. Moreover, it is not the first instance judgment. However, people steadily repeat that doping is wrong because WADA told them about it. In hindsight, doping consumption and fight with it are identical from the moral perspective, because it is fully inappropriate to use such criteria of measurement. The mechanisms for 
doping usage or trying to get rid of it are far from the moral aspect due to the commercialization of professional sport and its connection with politics and material benefits.

Let's see what is doping to identify if it is as dangerous as described and is it possible not to use it at all in the professional sport. Under certificates of traditional historians, even in the 3rd century BC during the Olympic Games in Ancient Greece, the Olympians thought of all sorts of stratagems to increase the possibilities to win. For example, regular consumption of sesame seeds helped a runner to increase endurance and stamina. Also, the wrestlers ate ten pounds of lamb taken with red wine and a tiny portion of strychnine right before the beginning of competitions. As for the term 'doping,' it was the name of one drink, some South African tribes used while doing their ancient rituals. Doping as a stimulant came to the big sport only at the beginning of the last century, although such stimulants and enhancers were given to animals, not to the people [7].

To understand the idea of the doping origin, let's see WADA's history. This anti-doping organization was founded in 1999 [7] although it often seems that WADA appeared with the Universe creation. It has been significantly developed in the last ten years that it is hard to believe that the Olympic Games champions from Pythagoras and Plato's times successfully escape the unexpected break-ins of anti-doping commissars with the purpose to run blood tests for prohibited substance. Also, nobody asks why the company with headquarters in Canada generates a list of so-called 'banned' drugs and send its emissaries across the ocean to check a person regarding his or her consumption of stimulants from the list only because he or she is involved in doing professional sport.

Speaking of competitions, we need to mention that it has not associated with healthy lifestyle any longer. Nowadays, games turned into big financial industries aiming to make a profit. Being a professional sportsman is now recognized as a well-paid job. Talented juniors have to make a constant progress improving their results to get promotion and bonuses. If we compare a working day of an ordinary person with a workload of athletes, the result will impress a lot. If regular citizens feel exhausted after work, it is easy to imagine how athletes feel training 24/7 without rest. Thus, to maintain stamina and endurance, athletes should take some pills to maintain their performance and improve blood circulation.

Thirty percent of coaches ensure that removal of any drugs from the big sport will cause a plunge of results. Since professional tournaments have become a way to make a living and provide families with all necessary goods and supplies, athletes will do everything to break records. In fact, it will make their names attractive for numerous sponsored by the wealthiest famous companies' contracts and advertisements as well as commercial competitions to provide steady annual income. Immoral? It is undoubtedly so, but if athletes are the only one family members responsible for their relatives' support, it is tough to judge them at all.

At the beginning of the Olympic Games ceremony, the head of the International Olympic Committee calls for 'clean and fair sport' without any drugs. Nevertheless, it is tricky to explain the division of all medicine into prohibited and approved for usage. WADA's members define which drugs to ban, but which to authorize for consumption. Every day people consume substances such as coffee, cigarettes, energetics, vitamins, etc., stimulating body's functioning and increasing performance. Furthermore, in the case of feeling sick or sleepdeprived, a worker usually takes some drugs to recover and continue to work, and nobody condemns it.

The pharmaceutical industry consistently manufactures dietary supplements, protein cocktails, weight loss and slimming helpers, injections of beauty and much other stuff to prolong the beauty and life expectancy [7]. Athletes are human beings who need to keep fit for many reasons. If meldonium is the first drug for those who suffer from high blood pressure and heart disorders, why cannot athletes use it to keep from heart attacks? There is still no clear picture how to recognize what medication is not dangerous and if there is any guarantee that such drugs not to be banned by WADA for several years as it happened with meldonium [6].

Sport is also a political issue nowadays. Each country considers sports victories as proofs of its power and strength. The leaders in the big game have always been under tremendous pressure regarding the medals of global tournaments such as Olympiads, World Cups, Sports Leagues, etc. The calculation of potential medals is the most stupid thing that has ever happened to humanity. At the same time, even much before the start of competitions, sports commentators, analytics and bookmakers lay their bets on a likelihood of prizes and victories. Moreover, audience demands dramatic spectacles. Otherwise, nobody will watch competitions on TV or attend stadiums. It will cause the bankruptcy of sports clubs, which make money from ticket sales and investments from ads athletes. Finally, there are fan groups, who tend to love athletes or teams at the time of success. However, sympathies of the public can immediately turn into envy, in the case of bad performance of athletes. In particular, it happened with Aaron Ramsey, being booed by spectators due to his poor results despite the evidence of his nagging injuries [1].

In conclusion, WADA's approach to making everyone suspicious made the situation even more critical. Sums of money for first three positions are growing from year to year, and, therefore, athletes will cheat under any circumstances and despite all kinds of punishment. If the society wants to get rid of drugs, it is necessary to reconstruct the entire sports system, restricting all drugs, no matter if they are on WADA's list or not. People without any health problems must make a professional game. If athletes are diagnosed with asthma, such as the biggest part of Scandinavian biathlons, they should not compete at all. Time will pass before people get used to 
performing lower results or earning less money for participation in tournaments. Calculation of medals and pressure on athletes before and afterward must be forbidden. Is it possible? The answer is negative unless money is the first thing of humanity's concerns. Furthermore, even if to restrict the usage of all drugs, there is no guarantee that people will not take in any illegal pills to win due to their competitive nature and additional merits in the future, reflected the ancient traces of the drug usage.

To sum up, doping should be legalized in the sport of the highest achievements as long as it is the way of making a living. The actions of the athletes do not threaten the entire society, and, therefore; there is no reason why doping in the global game should be considered as something immoral. The matter of health is the issue of every person. They are free to take such a risk. As for the care of human health, it will be much more efficient to forbid entirely any alcohol or nicotine. Sport should be returned to its original idea - to reveal the strongest athlete, but not the most powerful country. Perhaps, only this decision will help to switch the attention of the world authorities from sport to the number of schools and kindergartens, the attrition rate, the utilizing the workforce efficiently, the reducing the number of fatal consequences, increasing the child allowance and many other things [4].

\section{References}

1. Arsenal's Arsene Wenger slams Stoke City fans for Aaron Ramsey chants. [Electronic resource]. URL: http://www.espnfc.com/arsenal/story/2789089/arsene-wenger-of-arsenal-slams-stoke-fans-for-ramsey-chants (date of access: 25.08.2016).

2. Backhouse McKenna, Atkins \& Robinson. The Psychology of Doping in Sport, 2015. doi:10.4324/9781315761107.

3. Dimeo P. Why Lance Armstrong? Historical Context and Key Turning Points in the 'Cleaning Up' of Professional Cycling. The International Journal of the History of Sport, 2014. 31 (8). 951-968. doi:10.1080/09523367.2013.879858.

4. Mcnamee M. Sport, ethics, and philosophy; context, history, prospects. Sport, Ethics, and Philosophy. 1 (1), 2004. 1-6. doi:10.1080/17511320601173329.

5. Mcnamee $M$. Lance Armstrong, anti-doping policy, and the need for ethical commentary by philosophers of sport. Sport, Ethics and Philosophy, 2012. № 6 (3). P. 305-307. doi:10.1080/17511321.2012.708252.

6. Meldonium uses widespread among elite athletes. Clinical Pharmacist, 2016. doi:10.1211/cp.2016.20200868.

7. Starzak Derman, McKune \& Semple. Anti-Doping Knowledge and Opinions of South African Pharmacists and General Practitioners [Abstract]. Journal of Sports Medicine \& Doping Studies, 2016. № 6 (3). 1000181st ser. doi: 2161-0673.1000181. 